\title{
Estudo Dogmático da Forma dos Atos Processuais (Princípios e espécies)
}

\section{Otávio Luiz Rodrigues Junior}

Doutorando em Direito Civil - Faculdade de Direito da Universidade de São Paulo. Advogado da União. Ex-Assessor Jurídico do Comando do 80 Distrito Naval - São Paulo. Professor do Curso de Direito do Centro Universitário de Brasília UniCeub. Professor licenciado dos Cursos de Direito da Faculdade 7 de Setembro. 



\section{Estudo Dogmático da Forma dos Atos Processuais PRINCÍPIOS E ESPÉCIES ${ }^{1}$}

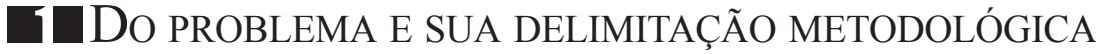

O problema analisado neste artigo é a forma dos atos processuais, vista sob o aspecto de seus princípios e de suas espécies.

Os atos processuais podem ser vislumbrados sob vários prismas, como bem ressaltou Alfredo de ARAúJo LoPES DA COSTA ${ }^{2}$ : permissibilidade, agentes, lugar, tempo, forma, natureza, correção ou interdependência. Entretanto, esse trabalho cuidará apenas de sua forma e de suas espécies.

O estudo é dogmático. Não se pretende desenvolver, salvo quando indispensável, considerações de ordem especulativa. Em suma, ocupa-se de oferecer uma sistematização doutrinária sobre a matéria, tomando como vértice o chamado estado-da-arte em termos de Ciência do Direito Processual. A jurisprudência tão-somente servirá como índice da aplicação das construções teóricas pesquisadas.

A exposição dividir-se-á em três secções: $a$ ) descrição e conceito das categorias fato processual e ato processual e seu vínculo com a noção de forma; $b$ ) inventário dos princípios inerentes à forma dos atos processuais; c) taxinomia dos atos processuais.

${ }^{1}$ Estudo originalmente publicado na Revista Jurídica no 321, de julho de 2004, p.51-72, Porto Alegre, e, posteriormente, em versão modificada e ampliada, apresentado sob a forma de palestra na III Semana FA7 de Direito, realizada em Fortaleza, Ceará, 24 de setembro de 2004.

${ }^{2}$ Direito processual civil brasileiro. 2 ed. revista. Rio de Janeiro: Forense, 1959. v.2. p.111. 


\section{TI DOS ATOS PROCESSUAIS}

\subsection{DOS FATOS PROCESSUAIS E DOS ATOS PROCESSUAIS}

Os fatos processuais são eventos ou condutas, no âmbito do processo, que criam, modificam ou extinguem suas peculiares relações. A origem dessa expressão é comum a de fatos jurídicos, que se utiliza de uma variante do particípio passado do verbo fazer (feito, como encontrável em leis arcaicas, especialmente nas Ordenações Reinóis), associandose à idéia de mudança, dinâmica, transformação, criação e alteração. Os fatos contrapõem-se à inércia. E, por serem jurídicos, devem interferir precisamente nos vínculos, situações e relações timbrados pelas notas de bilateralidade, atributividade, intersubjetividade e sancionabilidade. ${ }^{3}$ A causa dos fatos processuais pode figurar nos chamados eventos (o fato jurídico-processual strictu sensu), ao estilo do falecimento da parte; da interrupção do serviço forense ou da perda dos autos por calamidade gerada por chuvas ou guerras; do decurso do tempo, conferindo ensanchas à prescrição. Também a conduta pode ser causa dos fatos processuais, entendida aquela como a ação do homem, fazendo surgir os atos processuais, em atenção ao agir, ao atuar da persona.$^{4}$ No fragmento 18 do Digesto (De verborum significatione, XIV), ULPIANo já pronunciava que actum quidem generale verbum esse, sive verbis, sive re agatur. ${ }^{5}$

Os fatos processuais em sentido lato seriam gênero em relação aos fatos processuais strictu sensu e aos atos processuais. Preponderante a essa departição é a causa: aos fatos imputam-se eventos, aos atos atribuemse condutas.

Os atos processuais são condutas que criam, modificam ou extinguem as relações jurídicas no processo. ${ }^{6}$

${ }^{3}$ Sobre o caráter de juridicidade como nota definidora dos fatos, ARNALDO VASCONCELOS (Teoria da norma jurídica. 2 ed. Rio de Janeiro: Forense, 1986. p.13) acentua que "o fato constitui a matéria do Direito, do qual a norma é a forma. Surge o Direito, precisamente, ao incidir esta sobre aquele. É ainda o fato, considerado no dinamismo de sua força social, responsável pelo progresso do Direito, promovendo-o a todo custo, quer através da interpretação evolutiva, quer mediante a reforma legislativa".

${ }^{4}$ A respeito de atos e fatos jurídicos: LOTUFO, Renan. Comentários ao código civil brasileiro. São Paulo: Saraiva, 2002. v.1.p.261

${ }^{5}$ CORPUS IURIS CIVILIS Academicum Parisiense. Opera et cura C. M. Galisset, Duodecima editio, Lutetiae Parisiorum: Rectores V. Renault et Consociati, MDCCCLXXXVIII.

${ }^{6}$ Nelton dos SAntos define ato processual como "toda conduta - praticada por um ou mais dos sujeitos da relação jurídica processual - que produza a criação, modificação ou extinção de situações jurídicas processuais.” (MARCATO, Antonio Carlos (Org.) Código de processo civil interpretado. São Paulo: Atlas, 2004. p.407.) 
Semelhante ordem é mui aproximada da que formula UGo Rocco: "Fatti giuridici diconsi tutti gli avvenimenti a cui il diritto obiettivo riannoda com conseguenza la nascita, modificazione o estinzione di um rapporto giuridico. I fatti giuridici processuali sono quegli avvenimenti processuali o quelle circostanze di fatto rilevanti, ai quali il diritto processuale obiettivo ricollega effetti giuridici processuali, cioè la nascita, modificazione o estinzione dei rapporti giuridici processuali. I fatti giuridici processuali si distinguono in fatti giuridici involuntari o fatti naturali (morte, nascita, tempo) $e$ fatti giuridici volontari (atti giuridici)"?

\subsection{Do NEGócio PROCESSUAL}

Há, ainda, a categoria negócio processual. ${ }^{8}$

Sua inspiração é evidente no negócio jurídico, um dos mais importantes conceitos que o Direito Civil ofereceu à Ciência Jurídica. ANTONIO JUNQUEIRA DE AZEVEDO define-o: “É a hipótese de fato jurídico (suporte fático), consistente em uma manifestação de vontade cercada de circunstâncias negociais que fazem com que socialmente essa manifestação seja vista como dirigida à produção de efeitos jurídicos."

A palavra negócio está relacionada com as expressões latinas actus e negotium. Conforme Álvaro VILlAÇA AzEVEDO, ambas veiculam idéias de contrariedade à estática: "O substantivo ato deriva do particípio passado do verbo latino ago, is, egi, actum, ere. Agere quer dizer agir, atuar. Negócio, a seu turno, vem de nec (não) otium, ii (ociosidade, quietude, ausência de atuação). Nec otium significa, portanto, sem ociosidade, movimento, atuação".

Correspondendo a uma sofisticação teórica do Direito Civil, especialmente a partir do século XIX, o negócio jurídico ganhou direito de cidade na ciência jurídica, havendo sido incorporado de modo expresso pelo

${ }^{7}$ Trattato di diritto processuale civile. Torino: UTET, 1957. v.2. p.195.

${ }^{8}$ Não é concernente ao objeto deste trabalho a situação do negócio jurídico processual como uma espécie de ato processual, figurando este como gênero. Essa é uma polêmica ainda insolvida no próprio Direito Civil, havendo defensores da divisão tripartida (negócio jurídico, atos meramente lícitos e atos ilícitos), como ANTONIO JUNQUEIRA DE AzEVEDo, e corifeus da departição em atos jurídicos lícitos (negócios jurídicos e atos meramente lícitos) e atos ilícitos, ao exemplo de José Carlos Moreira Alves, que viu suas idéias prevalecerem na codificação de 2002.

${ }^{9}$ Código civil comentado. São Paulo: Atlas, 2003. v.2. p.37. 
Código Civil de 2002 (art.104) ${ }^{10}$. No que diz com o Direito Processual Civil, já se fala em negócio jurídico-processual ou simplesmente negócio processual, embora, como advirta UGo Rocco, é uma nomenclatura ainda submetida a toda sorte de polêmicas na doutrina. ${ }^{11}$

É possível definir negócio jurídico-processual como uma declaração de vontade, unilateral ou bilateral, dirigida ao fim específico da produção de efeitos no âmbito do processo. São exemplos a revogação do mandato conferido ao advogado (art.44, CPC) ou a transação em juízo (art.267, inciso III, CPC). Numa óptica mais antiga, consideravam-se negócios processuais os procedimentos de jurisdição voluntária, o que, sem dúvida, é insustentável ante as contemporâneas noções do Processo Civil.

\subsection{Dos atos PROCESSUAIS E dos atos JUdiCiaIS: NOMENClatura}

Os atos processuais, como espécies de atos jurídicos, assim se qualificam pela conseqüência da atitude epistemológica de limitar sua eficácia ao universo exclusivo dos processos. Daí ser equívoca a denominação atos judiciais constante do Código de Processo Civil de 1939, por deixar de abranger atos praticados por outrem, que não apenas o magistrado. De semelhante impropriedade não se pode cumular o Código de Processo Civil de 1973, que acolheu o termo atos processuais, conforme a melhor tradição européia (actes de procédure, em França; atti processuali ou atti di procedura, na Itália; Prozeshandlunge, no direito germânico e austríaco). O BARÃO DE RAMALHO, para invocar também a mais antiga e respeitável doutrina nacional, adotou a terminologia "atos do processo". ${ }^{12}$

\section{[1] DA FORMA DOS ATOS PROCESSUAIS: PRINCÍPIOS}

\subsection{Das generalidades}

A forma é o modo exterior de um ser. A rigor, nada diz com sua essência. A forma não deveria integrar o plano da existência. Entretanto, os fenômenos jurídicos apresentam uma peculiaridade: sua abstração torna o modo-de-ser um elemento do próprio ser. Daí a forma, no âmbito específico da Ciência do Direito, integrar o plano da existência, exibindo o caracter de seu elemento.

\footnotetext{
${ }^{10}$ Art. 104. A validade do negócio jurídico requer: I - agente capaz; II - objeto lícito, possível, determinado ou determinável; III - forma prescrita ou não defesa em lei.

${ }^{11}$ Op. cit. p.196.

${ }^{12}$ In. Praxe. Rio de Janeiro: (s.e), 1867. p.163
} 
Em tal medida e sob esse fundamento, não se podem analisar as manifestações jurídicas sem atenção ao elemento formal, ainda que este não seja solene, escrito ou incorporado em um meio físico, capaz de reproduzir no espírito sua perpétua e recorrente memória.

Ao tempo do período formulário, no Direito Romano, as formas eram sacramentais. Digno de lembrança é o caso do litigante que perdeu a ação (rectius, teve os pedidos de sua ação considerados improcedentes) pelo fato de haver trocado a palavra arbor (árvore) por vitis (videira), num processo em que se discutia a responsabilidade pelo corte do arbusto alheio. Tal solução somente será possível no que chamamos de sistema da legalidade estrita da forma. A violação dos requisitos formais ensejaria a nulidade do ato. ${ }^{13}$

Em outro extremo, há o sistema da soberania do juiz, típico do regime do common law, no qual o magistrado define a forma adotada e como ela será mais útil em cada caso. Como limites a essa discricionariedade, têm-se os precedentes pretorianos, os costumes e, eventualmente, a lei.

Há, ainda, o sistema da liberdade da forma para a parte, também identificável no sistema anglo-americano, na fase do pre-trial, instante em que os contendores tentam solucionar o litígio, sob a fiscalização do juiz, produzindo atos que podem extinguir a demanda sem que se chegue ao júri ou à decisão da Corte. ${ }^{14}$

A definição desses sistemas e o tratamento jurídico da forma no direito brasileiro passam pela investigação de seus princípios reitores.

Assim, as próximas secções ocupar-se-ão dos seguintes primados: $a$ ) princípio da liberdade de forma ("os atos e termos processuais não

\footnotetext{
${ }^{13}$ LOPES DA COSTA, Alfredo de Araújo. Op. cit. p.135.

${ }^{14}$ C. G. VAN DER MERWE (A comparative study of the distribution of ownership rights in property in an apartment or condominium scheme in common law, civil law and mixed law systems. In. Georgia Journal of International and Comparative Law, v.31, n.1, p.101-137, fall 2002) e José Carlos Barbosa Moreira (Uma novidade: o Código de processo civil inglês. In Revista de Processo, v.25, n.99, p.4-83, jul./set. 2000) anotaram as recentes mudanças no sistema processual anglo-americano, com a superação de alguns dogmas há muito repetidos sobre o modelo jurisdicional do Reino Unido (que está agora sob o regime de um novo Código de Processo Civil) e dos Estados Unidos (em que mais e mais se ampliam os poderes do juiz, antes um autêntica testemunha imparcial).
} 
dependem de forma determinada senão quando a lei expressamente a exigir" - art.154, CPC); b) princípio da instrumentalidade das formas (reputam-se válidos os atos que, mesmo realizados de outro modo, atendam a sua finalidade essencial - art.154, CPC); c) princípio da publicidade dos atos processuais (art.155, CPC); d) princípio da vernaculidade (art.156 c/c art.157, CPC).

\subsection{DO PRINCÍPIO DA LIBERDADE DE FORMA}

O princípio da liberdade de forma inspira-se na autonomia da vontade $^{15}$, prestigiador da capacidade criadora de atos e negócios jurídicos pelas partes (art.107, CCB-2002) ${ }^{16}$. A forma (elemento do plano da existência), quando submetida ao plano da validade, basta que não vulnere norma específica a seu respeito ou adote meio exterior contrário a seus parâmetros. A forma prescrita, por assim, ocorrerá em casos excepcionais. ${ }^{17}$

No direito brasileiro, portanto, conjugam-se elementos do sistema da legalidade da forma, com severas supressões, e do sistema da liberdade de forma, também submetido a respeitáveis temperamentos.

\subsection{DO PRINCÍPIO DA INSTRUMENTALIDADE DAS FORMAS}

O Direito Processual vai além e estatui um modo de superação da invalidez formal, mediante o primado de que se devem aproveitar os atos, desde que, a despeito de sua imperfeição exterior, atendam a seus fins essenciais (princípio da instrumentalidade das formas ou princípio da finalidade). Bem entendido, não causem prejuízo (pas de nulité sans grief) e, a seu modo, cumpram eficazmente os objetivos da lei. A respeito escreveu Francisco Cavalcanti Pontes de Miranda:

${ }^{15}$ Sobre autonomia da vontade: RODRIGUES JUNIOR, Otavio Luiz. Revisão judicial dos contratos: Teoria da imprevisão e autonomia da vontade. São Paulo : Atlas, 2002. p.34-35; ROMANO, Salvatore. Autonomia privata. Milano: Giuffrè, 1957. passim; AZEVEDO, Antonio Junqueira de. Ciência do direito, negócio jurídico e ideologia. In. DI FRANCESCO, José Roberto Pacheco. Estudos em homenagem ao professor Silvio Rodrigues. São Paulo: Saraiva, 1989. p.14.

${ }^{16}$ Art. 107. A validade da declaração de vontade não dependerá de forma especial, senão quando a lei expressamente a exigir.

${ }^{17}$ Humberto Theodoro JúnIOR (Curso de direito processual civil. 39 ed. Rio de Janeiro: Forense, 2003. v.1.p.200) refere que os atos processuais são solenes, embora esse caracter ceda espaço à finalidade essencial dos mesmos. 
"Tão importante é a finalidade dos atos que o art.154 tem por válidos os que, realizados por modo diferente daquele que a lei exige, têm preenchida a finalidade. A lei pode exigir uma forma ou não a exigir. Se a exige, ou comina nulidade, ou não a comina: nem toda exigência leva consigo a sanção de nulidade. $\mathrm{O}$ art.154 não se pode interpretar como se houvesse dito que, se a lei exigiu, expressamente, determinada forma, e a falta de algum elemento invalidaria o ato ou termo, os atos realizados de outro modo lhe fariam às vezes. Supôs-se que a lei adotou determinada forma, mas, a despeito disso, o ato praticado preencheria a finalidade essencial. Tem-se de examinar, no caso, se o ato ou termo podia se realizado de outro modo. Depois, se, a despeito de não ter sido por outra forma, podia ter validade e eficácia". ${ }^{18}$

São exemplos desse princípio, todos extraídos da casuística pretoriana: a) tem-se por suprida a ausência de intervenção do Ministério Público nas causas em que esta é obrigatória, desde que inexista prejuízo à parte legalmente protegida, o que se dá, especialmente, na hipótese de sentença que lhe é favoráve $1^{19} ; b$ ) “é de ser mitigado o rigor do art. 525, do CPC, para, consideradas as peculiaridades do caso concreto, dispensar a certidão de intimação do ato agravado quando possível a verificação da tempestividade do recurso"; c) "o princípio da instrumentalidade das formas, aplicado à teoria geral dos recursos, induz a que se aplique a fungibilidade recursal desde que o recurso erroneamente interposto não importe em erro grosseiro, que haja dúvida objetiva quanto ao recurso pertinente, e que tenha sido lançado dentro do prazo daquele que seria correto". ${ }^{20}$

Para sintetizar esse princípio, os italianos usam de uma expressão mui precisa: a forma deve ser o mais idônea possivel ao fim colimado (forma piú idonea allo scopo). ${ }^{21}$ Daí haver assim definido o art.244, CPC: "Quando a lei prescrever determinada forma, sem cominação de nulidade, o juiz considerará válido o ato se, realizado de outro modo, lhe alcançar a finalidade".

${ }^{18}$ Comentários ao código de processo civil. Atualizado por Sergio Bermudes. 4 ed. Rio de Janeiro: Forense, 1998. v.3.p.47

${ }^{19}$ Superior Tribunal de Justiça. RESP n ${ }^{\circ}$ 289231/SC. 1a Turma. Rel. o Sr. Min. José Delgado. DJU de 26-3-2001, p.390.

${ }^{20}$ Superior Tribunal de Justiça. RESP n ${ }^{\circ} 151668 /$ SP. $4{ }^{\text {a }}$ Turma. Rel. o Sr. Min. CÉSAR ASFOR Rocha. DJ 11-9-2000, p.253.

${ }^{21}$ ROCCO, Ugo. Op. cit. p.261. 
Decorrência lógica do princípio da instrumentalidade das formas ou da finalidade constituem-se os primados da economia processual e da celeridade.

CÂNDIDO RANGEl DinAMARCO ${ }^{22}$, ao defender que o processo não é um fim em si mesmo, mas seu objetivo seria a realização do direito material com paz na sociedade, permite inferir o princípio da economia como sendo a obtenção do máximo resultado com o menor desperdício de tempo e esforço possível. Estabelecer-se-ia uma relação de custobenefício entre a formalidade dos atos e o atendimento a seus fins últimos. Exemplos concretos da incidência desse primado são observáveis na jurisprudência do Superior Tribunal de Justiça, quando, em seus acórdãos admite-se que "embora cabível e até mesmo recomendável a denunciação à lide de servidor público causador de dano decorrente de acidente de veículo, uma vez indeferido tal pedido, injustificável se torna, em sede de recurso especial, a anulação do processo para conversão do rito sumário em ordinário e admissão da denunciação, em atenção aos princípios da economia e celeridade processuais". E, em outros julgados, que "em nome da celeridade e da economia processual, admite-se e recomendase que o servidor público, causador do acidente, integre, desde logo, a relação processual. Entretanto, o indeferimento da denunciação da lide não justifica a anulação do processo". ${ }^{23}$ Por fim, pronunciou-se que "os princípios da economia e da celeridade podem justificar a não anulação parcial do processo onde indevidamente não se admitiu denunciação da lide (CPC, art. 70, III), ressalvado ao denunciante postular seus eventuais interesses na via autônoma". ${ }^{24}$

A celeridade é outro princípio conexo à instrumentalidade das formas. Numa perspectiva do Processo Civil eficaz, as remoras inerentes às demarchas jurisdicionais podem ser agravadas por práticas excessivamente formais, tornando imperativa a invocação desse primado.

Não se admite, porém, que, em detrimento da forma, se subvertam a essência do ato e sua finalidade, cuja expressão está em seu modo de ser. ${ }^{25}$ A instrumentalidade formal não pode aniquilar outros valores de

${ }^{23}$ Superior Tribunal de Justiça. Primeira Turma. REsp n ${ }^{\circ}$ 165411/ES. Rel. o Sr. Min.GARCIA VIEIRA. DJU de 3-8-1998, p.125.

${ }^{24}$ Superior Tribunal de Justiça. REsp no 11599/RJ. Rel. Min. SÁlvio de Figueiredo TEIXEIRA. RSTJ 63/212.

${ }^{22}$ In. A instrumentalidade do processo. 10 ed. São Paulo: Malheiros, 2002.p. 22.

${ }^{25}$ Nesse sentido: MONIZ DE ARAGÃO, E. D. Comentários ao código de processo civil. 9 ed. rev., atual. Rio de Janeiro: Forense, 1998. v.2. p.13. 
equivalente relevo, como a segurança jurídica, a certeza dos atos ou igualdade substancial entre as partes ${ }^{26}$, o que sói poderia ocorrer se fosse instaurado um regime de franca atipicidade das declarações e dos provimentos em juízo. ${ }^{27}$

Exemplificando esse desvio, ter-se-ia o caso do deferimento de uma petição inicial que ignorasse a obrigatoriedade de se imputar o valor da causa, conforme o art.258, CPC. O juiz, ao fazê-lo, invocaria o princípio da instrumentalidade formal: o quantum econômico restaria implícito na causa petendi, porquanto ali se noticiou um dano emergente de milhares de reais. O comando do art.258, CPC, poderia ser afastado. Nessa situação, a acolhida radical do primado da forma livre transmutar-se-ia em derruição mesma do princípio da legalidade.

\subsection{Do PRINCíPIO DA PUBLICIDADE dOS ATOS PROCESSUAIS}

\subsubsection{De seu fundamento constitucional}

A publicidade dos atos processuais tem duplo fundamento constitucional. Um genérico, "a lei só poderá restringir a publicidade dos atos processuais quando a defesa da intimidade ou o interesse social o exigirem" (art. $5^{\circ}$, LX, CF/1988). Outro específico para os atos processuais dotados de conteúdo decisório: “todos os julgamentos dos órgãos do Poder Judiciário serão públicos, e fundamentadas todas as decisões, sob pena de nulidade, podendo a lei, se o interesse público o exigir, limitar a presença, em determinados atos, às próprias partes e a seus advogados, ou somente a estes" (art.93, IX, CF/1988).

\subsubsection{De seu fundamento legal}

Atribuindo eficácia imediata à indicção constitucional, o Código de Processo Civil (art.155) clausula como submetidos ao "segredo de justiça" não somente os atos processuais, mas seu conjunto concatenado (os

\footnotetext{
${ }^{26}$ Sobre a igualdade entre as partes no processo, essa excelente tese de doutoramento: VIANA, Juvêncio Vasconcelos. Efetividade do processo em face da fazenda pública. São Paulo: Dialética, 2003. passim

${ }^{27}$ ROCCO, Ugo. Op. cit. p.260: “Questo complesso di formalità è posto e stabilito dalla legge processuale per assicurare e garantire alle parti uma retta giustizia e per eliminare ogni incertezza, circa lê vie da seguire per ottenere tale giustizia, con la osservanza del principio del contraddittorio e della eguaglianza delle parti in giudizio, stabilendo una corrente di azioni e reazioni, che limitano, ad un tempo, i poteri del giudice e delle parti stesse".
} 
processos), conforme exijam o interesse público e as relações do status familiae (casamento; filiação; separação dos cônjuges e sua conversão em divórcio; alimentos e guarda de menores) ${ }^{28}$

\subsubsection{Da necessidade de interpretação do princípio da publicidade em face de suas exceções: segredo de justiça fundado em interesse público, interesse social, intimidade das partes e ações referentes ao status familiae}

A melhor exegese do princípio da publicidade dos atos processuais, especificamente no que concerne a suas exceções, é a que se funda nos seguintes postulados:

\subsection{3.a) Da afetação do interesse público ao interesse social e à necessidade de difusão dos atos processuais}

A simples presença do interesse público não é causa justificadora do segredo de justiça, pois, a publicidade é a forma mais positiva de homenageá-lo (art.37, caput, CF/1988). Para JosÉ AdÉRCIO LeITE $\mathrm{SAMPAIO}^{29}$, as ações que envolvam exercentes de funções ou cargos de índole político-administrativa devem merecer tratamento diferenciado, preservando-se o sigilo apenas em atenção a valores radicais inerentes à intimidade ou ao interesse social. Semelhante postura deve ser observada mesmo em face de casos específicos de restrição à publicidade, como

${ }^{28}$ Há ainda outros casos: a) Lei $n^{\circ} 9.278$, de 10-5-1996: “Art.9 - Toda a matéria relativa à união estável é de competência do juízo da Vara de Família, assegurado o segredo de justiça"; b) Lei $\mathrm{n}^{\circ}$ 8.560, de 29-12-1992: “Art.2º. Em registro de nascimento de menor apenas com a maternidade estabelecida, o oficial remeterá ao juiz certidão integral do registro e o nome e prenome, profissão, identidade e residência do suposto pai, a fim de ser averiguada oficiosamente a procedência da alegação. (...) $\S 2^{\circ} \mathrm{O}$ juiz, quando entender necessário, determinará que a diligência seja realizada em segredo de justiça."; c) Lei nº 8.069, de13-7-1990 (Estatuto da Criança e do Adolescente): “Art.143. É vedada a divulgação de atos judiciais, policiais e administrativos que digam respeito a crianças e adolescentes a que se atribua autoria de ato infracional. Parágrafo único. Qualquer notícia a respeito do fato não poderá identificar a criança ou adolescente, vedando-se fotografia, referência a nome, apelido, filiação, parentesco, residência e, inclusive, iniciais do nome e sobrenome." e "Art.144. A expedição de cópia ou certidão de atos a que se refere o artigo anterior somente será deferida pela autoridade judiciária competente, se demonstrado o interesse e justificada a finalidade."; d) Código Civil de 2002: "Art.1.705. Para obter alimentos, o filho havido fora do casamento pode acionar o genitor, sendo facultado ao juiz determinar, a pedido de qualquer das partes, que a ação se processe em segredo de justiça."

${ }^{29} \mathrm{In}$. Direito à intimidade e à vida privada. Belo Horizonte: Del Rey, 1998. p.61. 
os assinalados no art. $247^{30}$ da Lei Complementar $n^{\circ} 75$, de 20-5-1993 (Lei Orgânica do Ministério Público) ou no art.27, parágrafo sexto ${ }^{31}$, da Lei Complementar n 35, de 14-3-1979 (Lei Orgânica da Magistratura Nacional).

O interesse social, afetado ao interesse público, é o único determinante da exceção à regra de publicidade irrestrita dos atos. Explique-se. A preservação do interesse social é que deve suportar os desconfortos de uma censura à exteriorização dos atos do processo. Fazendo-o, findase por enaltecer o interesse público. Assim, todos os atos que impliquem, por sua difusão, abalos e comoções sociais desnecessários, capazes de periclitar os valores do Estado Democrático de Direito, devem e merecem ser inscritos na cláusula excepcional de censura, prevista genericamente na Constituição e nas leis ordinárias.

\subsection{3.b) Ampliação do rol de ações que admitem o segredo de justiça para além das modalidades inerentes ao status familiae}

Não basta a ocorrência das ações de estado para que se excepcione o princípio da publicidade. É necessária a conjugação dessa qualidade com o objetivo de preservação da intimidade das pessoas envolvidas, o que, por via de conseqüência, permite inferir que, nesse ponto, a redação do Código de Processo Civil é não apenas imprecisa, como também omissa.

Em outros termos: (i) Haverá ações de estado sem qualquer caráter ofensivo à intimidade das partes, como a separação consensual de cônjuges. (ii) Outras ações, por natureza, são em si mesmas detrimentosas, como as relativas a alimentos e à filiação, encontrando-se subentendida

${ }^{30}$ Art. 247. O inquérito administrativo, de caráter sigiloso, será instaurado pelo Corregedor-Geral, mediante portaria, em que designará comissão de três membros para realizá-lo, sempre que tomar conhecimento de infração disciplinar. § $1^{\circ}$ A comissão, que poderá ser presidida pelo Corregedor-Geral, será composta de integrantes da carreira, vitalícios, e de classe igual ou superior à do indiciado. $\S 2^{\circ}$ As publicações relativas a inquérito administrativo conterão o respectivo número, omitido o nome do indiciado, que será cientificado pessoalmente.

${ }^{31}$ Art.27. O procedimento para a decretação da perda do cargo terá início por determinação do tribunal, ou do seu órgão especial, a que pertença ou esteja subordinado o magistrado, de ofício ou mediante representação fundamentada do Poder Executivo ou Legislativo, do Ministério Público ou do Conselho Federal ou seccional da Ordem dos Advogados do Brasil. (...) $\S 6^{\circ} \mathrm{O}$ julgamento será realizado em sessão secreta do tribunal ou de seu órgão especial, depois de relatório oral, e a decisão no sentido da penalização do magistrado só será tomada pelo voto de dois terços dos membros do colegiado, em escrutínio secreto. 
a preservação da intimidade. (iii) E, tantas outras, alheias ao espectro do status familiae, como as ações ordinárias visando à prevenção ou à punição do dano moral, em que seu fimúltimo radica-se na intangibilidade de valores psíquicos ou sentimentais. Nesse derradeiro caso, a simples publicidade das ações já traduziria um dano maior que o sofrido pela parte autora $^{32}$.

Francisco Cavalcanti Pontes de Miranda vale-se do interesse público para defender a liciedade de segredar em juízo as matérias que causem humilhação, vexame ou embaraço à parte, ao Estado, à sociedade ou a terceiro. ${ }^{33}$ Para E. D. Moniz de Aragão, "a Constituição aumentou, pois, o poder discricionário dos juízes, que era menos amplo, e assim restringiu a incidência do princípio da publicidade dos atos processuais", estendendo-o para outros processos que não os arrolados no inciso I do art. 155, CPC. ${ }^{34}$

Veja-se que, em uma ação investigatória de paternidade, inserida na exceção de hermetismo judicial, o Superior Tribunal de Justiça admitiu sua publicidade, sob o color de que: "Essa notícia não viola o segredo de justiça, e mais há de ser considerado: ' $C$ ', líder político, Governador de Estado, enfim homem público cuja vida interessa aos seus coestaduanos, aos que estão sob o Governo, e mais até, a todos os brasileiros pela merecida projeção do Estado de Minas Gerais no concerto da Federação, não pode ser anônimo no seio da população brasileira...". 35

O inciso II do art.155 do Código de Processo Civil deveria, portanto, ser assim interpretado: correrão em segredo de justiça as ações que envolvam aspectos da vida íntima ou da privacidade das partes, permitindo-se ao juiz, nas ações de estado e afins, relativizar a restrição legal. ${ }^{36}$

${ }^{32}$ O Superior Tribunal de Justiça, analisando o caso de um jornal que publicara o resultado de um julgamento em investigatória de paternidade, entendeu que: "Liberdade de imprensa. Segredo de justiça. Simples notícia de julgamento da causa não lhe transgride o segredo de justiça" (RT 691/182).

${ }^{33}$ Op. cit. p.52.

${ }^{34}$ MONIZ DE ARAGÃO, E. D. Op. cit. p.16.

${ }^{35}$ RT 691/184.

${ }^{36}$ Em sentido contrário: PONTES DE MIRANDA, Francisco Cavalcanti. Op. cit. p.49, que afirma ser exigível sempre o segredo de justiça nas ações de estado. 
Veja-se, como apoio a essa tese, que, em diversos artigos, o Código de Processo Civil já assegura ao juiz a faculdade de inscrever algumas ações na cláusula do segredo judiciário (arts.815 $5^{37}, 823^{38}$ e 841 , caput $^{39}$ ), sem que, necessariamente, estejam vincadas aos tipos expressos do art.155. Nos procedimentos dos arts. 815 e 823 busca-se, em grande medida, preservar o interesse do requerente em face da real possibilidade de dilapidação do penhor geral de seus créditos, o patrimônio do requerido, no arresto, ou, a recuperação das cousas litigiosas, no seqüestro. ${ }^{40}$ Nas ações de busca e apreensão, prevalece o mesmo objetivo, a saber, impedir a evasão da pessoa ou do bem.

\subsubsection{Da Relatividade dos efeitos do segredo de justiça}

\subsection{4.a) Do segredo de justiça e seus efeitos relativos às partes $e$ aos procuradores}

O segredo de justiça tem caráter inter alios, não produzindo efeitos relativamente às partes mesmas e seus procuradores (art.155, parágrafo único). ${ }^{41} \mathrm{O}$ conceito de partes é o mais amplo possível, abrangendo autor, réu, assistente litisconsorcial, assistente simples, litisdenunciado, nomeado à autoria, chamado ao processo e opoente. ${ }^{42}$ Os juízes, órgãos do Ministério Público e serventuários a quem se comete processar tais ações encontram-se implícita e logicamente excluídos da condição de terceiros, respondendo, porém, a título de dolo ou culpa grave, pela ruptura do hermetismo imposto em lei.

${ }^{37}$ Art.815. A justificação prévia, quando ao juiz parecer indispensável, far-se-á em segredo e de plano, reduzindo-se a termo o depoimento das testemunhas.

${ }^{38}$ Art.823. Aplica-se ao seqüestro, no que couber, o que este Código estatui acerca do arresto.

${ }^{39}$ Art.841. A justificação prévia far-se-á em segredo de justiça, se for indispensável. (...)

${ }^{40}$ MONIZ DE ARAGÃO, E. D. Op. cit. p.18.

41 “O princípio da publicidade não diz apenas com o momento de produção do ato senão que também incide no que se refere à sua documentação. Destarte, afora o legalmente excepcionado (art. 155, I, II e parágrafo único), qualquer pessoa pode requerer, diretamente ao escrivão (que há de fornecer independentemente de despacho judicial), certidão de atos que se realizaram no processo (art. 141, V). De outro lado, ao advogado é assegurado o direito ao exame dos autos de qualquer processo, ‘quando não estejam sujeitos a sigilo'(art. $7^{\circ}$, XIII, da Lei 8.906, de 04.07.1994). Há de se entender que o disposto no parágrafo único do artigo em exame refere-se aos processos que correm em segredo de justiça e não à generalidade dos casos" (DALL'AGNOL, Antônio. Comentários ao código de processo civil. São Paulo: RT, 2000. v.2.p.231).

${ }^{42}$ Nesse sentido: PONTES DE MIRANDA, Francisco Cavalcanti. Op. cit., loc. cit. 
Portanto, não é vedada a comunicação dos atos às partes e a seus patronos. É mesmo necessária. ${ }^{43}$ Obviamente, impõem-se cautelas nesse mister, como ostentarem as publicações apenas a iniciais dos nomes dos litigantes, ${ }^{44}$ sem embargo do número do processo e a indicação dos procuradores. Asentença ou a interlocutória deve conter apenas elementos essenciais do dispositivo, de molde que terceiros não infiram de seu conteúdo uma ciência indevida.

Essa proibição de publicidade atina com: $a$ ) a vista, ${ }^{45}$ o acesso, o manuseio e a consulta aos autos, em secretaria ou fora dela; $b$ ) a extração

${ }^{43}$ O Superior Tribunal de Justiça entendeu que a sessão reservada nos julgamentos administrativos sob a égide da Lei Complementar no 35/1979 não deveria sê-lo em face dos advogados e dos juízes sindicados: "CONSTITUCIONAL EADMINISTRATIVO MAGISTRADO-PROCESSOADMINISTRATIVOPARAAPERDADOCARGO-RITO DA LEICOMPLEMENTAR 35/79(LOMAN)-ART.27- PROCEDIMENTOPRELIMINAR - SESSÃO RESERVADA-CONCLUSÃO-INSTAURAÇÃODAAÇÃO DISCIPLINAR E AFASTAMENTO DO JUIZ SINDICADO - AUSÊNCIA DE INTIMAÇÃO DO ADVOGADO CONSTITUÍDO - PREJUÍZO COMPROVADO - OFENSA AO CONTRADITÓRIOEAMPLADEFESA. I-Segundo estatui o art. 27 da Lei Complementar 35/79 (LOMAN), o procedimento preliminar que antecede à instauração da ação disciplinar para decretação da perda do cargo de magistrado, será concluído com a sessão reservada do Tribunal Pleno, ou do Órgão Especial, que tem por escopo decidir sobre a instauração do processo administrativo. II - O caráter secreto de tal reunião, todavia, não foi recepcionado pela Carta Política de 1988 que em seu art. 93, IX, instituiu que " todos os julgamentos serão públicos, e fundamentadas todas as decisões, sob pena de nulidade, podendo a lei, se o interesse público o exigir, limitar a presença, em determinados atos, às próprias partes e a seus advogados, ou somente a estes" " (ROMS n ${ }^{\circ}$ 15168/BA. Quinta Turma. DJU 28-10-2003, p.303 . Rel. o Sr. Min. GILSON DiPP ). Com idênticas conclusões: "ADMINISTRATIVO. MAGISTRADO. DISPONIBILIDADE. MANDADO DE SEGURANÇA. CERCEAMENTO DO DIREITO DE DEFESA. JULGAMENTOS PUBLICOS. 1. Configura cerceamento ao direito de defesa assegurado a toda pessoa, proibir a presença do magistrado ou do seu advogado no recinto da sessão, no momento da votação, ainda que tenham sido apresentadas as alegações finais, em processo onde é aplicada pena de disponibilidade. 2. Os julgamentos do Poder Judiciário são públicos e fundamentadas todas as decisões, sob pena de nulidade, sem vez a votação secreta. 3 . Ao Acusado ou ao seu defensor, segundo o interesse público o reclamar, não se pode negar o direito de acompanhar todo o processo, incluída a votação, quando poderá exemplo - fiscalizar se os votos foram secretos, se ocorreu alguma irregularidade, se votou quem não poderia fazê-lo. Enfim, defender-se não como um curioso, mas como interessado, visando a que o julgamento seja imparcial e sem vícios, uma vez que a decisão lhe interessa diretamente. 4 . Recurso provido parcialmente para declarar a nulidade do julgamento" (RSTJ 48/ 524).

${ }^{44}$ A favor: RJTJSP 105/301. Contrariamente: "Em se cuidando de intimação, há de se operar ela, como de ordinário, sendo indispensável, sob pena de nulidade, conforme previsão do art. 236, parágrafo único, o registro dos nomes das partes e de seus advogados, para o fim de identificação suficiente" (DALL'AGNOL, Antônio. Op. cit.p. 233).

${ }^{45}$ RT 527/59. 
de cópias; $c$ ) o direito a certidões; $d$ ) a participação em audiências ou sessões de julgamento, aqui incluída a presença nesses auditórios ou sua reprodução pública ou privada (fotografias, gravações, desenhos).

\subsection{4.b) Do segredo de justiça e seus efeitos relativos a terceiros}

Aos terceiros será permitido, desde que demonstrado interesse jurídico, tão-somente requerer certidão da parte dispositiva da sentença ou do acórdão, bem assim "de inventário e partilha resultante do desquite" (art.155, parágrafo único, in fine).

O interesse jurídico revela-se na demonstração dos efeitos reflexos do litígio no patrimônio jurídico do terceiro. ${ }^{46}$ Logo, afasta-se o interesse puramente humanitário, social ou político, sendo notável sua aproximação com o utilizado para qualificar o assistente simples. ${ }^{47}$ Se o terceiro não intervém nessa qualidade, pois a assistência é mera faculdade, pode, exibindo esse interesse jurídico, obter a certidão da parte dispositiva (a que menciona o art.155, CPC). Figurável, ainda, o caso das chamadas ações sub-rogatórias, que conferem ao credor a faculdade de exercer, em nome do devedor e em benefício de todos os credores, quaisquer de seus direitos patrimoniais, quando indispensável à conservação dos haveres do solvens, na definição de Fernando Noronha. ${ }^{48}$ O mesmo pode ser dito das ações diretas, quando "um credor pode exigir de quem seja devedor de seu devedor a importância por aquele devida a este". 49

Quanto à partilha da separação judicial, “o terceiro pode, desde que demonstre o seu interesse, requerer a expedição de carta de sentença visando ao registro da partilha em separação judicial". ${ }^{50}$

Oportuna a advertência de ANTÔNIO DALL'AGNOL sobre os limites desse acesso: "...o terceiro juridicamente interessado tem acesso apenas à documentação dos atos processuais realizados em processo que corra

${ }^{46}$ Em sentido mais amplo: "Qualquer pessoa, porém, desde que o requeira ao juiz da causa e lhe demonstre ter interesse jurídico, poderá pleitear certidão do dispositivo da sentença ou do inventário e partilha subseqüente ao desquite. Essa enumeração não parece capaz de esgotar as hipóteses que a prática pode oferecer. Destarte, se algum outro caso surgir, em que o terceiro demonstre certidões ou cópias, deverá o juiz deferi-las" (MONIZ DE ARAGÃO, E. D. Op. cit. p.19).

${ }^{47}$ Art. 50. Pendendo uma causa entre duas ou mais pessoas, o terceiro, que tiver interesse jurídico em que a sentença seja favorável a uma delas, poderá intervir no processo para assisti-la.

${ }^{48}$ Direito das obrigações. São Paulo: Saraiva, 2003. p.179.

${ }^{49}$ NORONHA, Fernando. Op. cit. p.180.

${ }^{50}$ JTJ 192/258. 
em segredo de justiça; acesso nenhum tem no momento da realização do ato. No que se refere a esse momento, o terceiro juridicamente interessado não se distingue de qualquer outro terceiro". ${ }^{51}$

\subsection{DO PRINCÍPIO DA VERNACULIDADE}

\subsubsection{De seu conceito}

O princípio da vernaculidade possui enunciado bastante elementar: "em todos os atos e termos do processo é obrigatório o uso do vernáculo" (art.156, CPC). O vernáculo corresponde à língua portuguesa, idioma oficial da República Federativa do Brasil por expressa determinação magna (art.13, caput, CF/1988) ${ }^{52}$. Inexistia semelhante norma no Código de Processo Civil de 1939.

\subsubsection{A quem vincula o princípio da vernaculidade}

Decorre desse princípio que os atos processuais das partes, do juiz, dos intervenientes, dos terceiros, dos serventuários e quaisquer outros que acorram ao processo devem ser necessariamente vazados em português.

\subsubsection{Do sentido da expressão "obrigatório o uso do vernáculo"}

O obrigatório constante do art.156, CPC, quer significar que é condição necessária para a validez do ato sua expressão no uso vernacular. Daí entender-se obrigatório como essencial, mas não exclusivo. Em melhores termos, exige-se o emprego do idioma português, sem, contudo, vedarse o concurso de expressões estrangeiras, desde que traduzidas. $\mathrm{O}$ Supremo Tribunal Federal, mesmo em um procedimento de habeas corpus, pronunciou que a petição deveria ser redigida em idioma nacional, dela não conhecendo por escrita em espanhol. ${ }^{53}$

${ }^{51}$ Op. cit. p.232.

${ }^{52}$ Art. 13. A língua portuguesa é o idioma oficial da República Federativa do Brasil.

53 "Habeas corpus - Impetração redigida em língua espanhola - Extradição - Formulação de pedido de clemência ao presidente da República - Ausência de indicação de ato configurador de ilegalidade ou abuso de poder - HC não conhecido. - É inquestionável o direito de súditos estrangeiros ajuizarem, em causa própria, a ação de habeas corpus, eis que esse remédio constitucional - por qualificar-se como verdadeira ação popular - pode ser utilizado por qualquer pessoa, independentemente da condição jurídica resultante de sua origem nacional. - A petição com que impetrado o habeas corpus deve ser redigida em português, sob pena de não-conhecimento do writ constitucional (CPC, art. 156, c/c CPP, art. 3.), Eis que o conteúdo dessa peça processual deve ser acessível a todos, sendo irrelevante, para esse efeito, que o juiz da causa conheça, eventualmente, o idioma estrangeiro utilizado pelo impetrante. A imprescindibilidade do uso do idioma nacional nos atos processuais, além de corresponder a uma exigência que decorre de razoes vinculadas a própria soberania nacional, constitui projeção concretizadora da norma inscrita no art. 13, caput, da carta federal, que proclama ser a língua portuguesa 'o idioma oficial da República Federativa do Brasil'”' (Supremo Tribunal Federal. Pleno. HC n' 72391-QO/DF. Rel. o Sr. Min. Celso de Mello. j. 8-3-1995, DJU 17-3-1995, p.5791). 


\subsubsection{Dos documentos em língua estrangeira}

Quanto aos documentos em língua estrangeira, o art.157, CPC, define que sua juntada somente poderá ser deferida quando acompanhados de versão em português, firmada por tradutor juramentado. Note-se que se não cuida de petições, mas, de documentos. Nesse tocante, excluemse as manifestações processuais das partes dirigidas ao juízo.

O Código de Processo Civil adotou o sistema da tradução documental obrigatória, conservando a tradição oriunda do Código de 1939. ALei de Registros Públicos, em seu art.129, inciso $6^{\circ}$, também determina que para produzirem efeito "em qualquer instância, juízo ou Tribunal” estão sujeitos a registro em títulos e documentos, "todos os documentos de procedência estrangeira, acompanhados das respectivas traduções". Havendo o Supremo Tribunal Federal admitido essa exceção: "Para produzir efeito em juízo não é necessária a inscrição, no registro público, de documentos de procedência estrangeira, autenticados por via consular" (Súmula $n^{\circ} 259$ ). O enunciado, por óbvio, trata do caso específico de documentos estrangeiros já autenticados por agente diplomático. Fora disso, aplica-se a regra geral.

A inexistência de tradutor juramentado na comarca admite seja suprida pelos meios gerais utilizados nas perícias, quando não se é possível louvar em expertos. ${ }^{54}$ NeLton dos SANTOS assinala que essa hipótese somente se coloca quando a parte já não tiver providenciado, em outra comarca, a versão em português do documento por tradutor sob juramento. ${ }^{55}$

\subsubsection{Das citações de autores estrangeiros nos atos processuais}

Interessante observar, no que se refere às petições e aos pronunciamentos judiciais, o hábito avoengo, de erudição duvidosa, de fazer citações nãotraduzidas, especialmente em línguas pouco versadas no Brasil. Ao tempo do Código de Processo Civil de 1939 essas abundavam, daí a inclusão expressa do princípio da vernaculidade no atual diploma, capaz de abranger não apenas os documentos, mas, também, os termos e atos processuais.

${ }^{54}$ MONIZ DE ARAGÃO, E. D. Op. cit. p.21. Em sentido contrário, exigindo-se a expedição de carta precatória: PONTES DE MIRANDA, Francisco Cavalcanti. Op. cit. p.60.

${ }^{55}$ MARCATO, Antonio Carlos. Op. cit. p.415. 
Ante esse problema, haveria invalidade nos atos que contenham textos de doutrinadores estrangeiros?

O uso do vernáculo é obrigatório nos atos e termos processuais (art.156, CPC).$^{56}$ Quanto a isso não há dúvidas. Entretanto, essa regra deve ser interpretada em respeito às peculiaridades de certas manifestações no processo, como é o caso das petições iniciais, respostas do réu e razões de recurso. Posto que tais peças não sejam textos científicos, a transcrição de autores estrangeiros como sustentáculo dos fundamentos jurídicos, sem a tradução devida, não confronta o art.156, CPC. ${ }^{57}$ Mesmo entendidos com a devida moderação, os princípios "da mihi factum, dabo tibi jus" e "jura novit curia" servem para figurar a imprescindibilidade de que a apenas se dê obrigatoriamente em vernáculo a narração, pois os textos legais de índole federal são de conhecimento pelo magistrado, incumbindo-lhe aplicar o direito, mesmo que se omita a parte em decliná-lo (RSTJ 21/432; RTJ 105/1.024, 115/932, RT 504/ 116, 608/153, RJTJESP 43/138, 50/281, 93/185, 115/119, JTA 88/ 335, RF 255/253). ${ }^{58}$ Logo, a parte que se vale de trechos doutrinários ou jurisprudenciais estrangeiros, está apenas suportando o risco de sua ignorância pelo órgão julgador, que pode muito bem decidir com o suporte da narração fática, esta a única a ser vazada ex necessitate em obrigatório vernáculo. Há, por conseguinte, arestos no sentido de que cópia de obra jurídica em língua estrangeira não está sujeita a tradução (JTA 117/163).

Ao Latim, entende-se deva ser conferido um tratamento ainda mais específico. Não se cuida de um idioma estrangeiro, embora utilizado até hoje nas comunicações oficiais de um Estado, a Santa Sé. O Latim é um instrumento léxico auxiliar em várias ciências (Anatomia, História Natural, Biologia, Geologia). No Direito, sua presença é extremamente

\footnotetext{
${ }^{56}$ Art. 156. Em todos os atos e termos do processo é obrigatório o uso do vernáculo.

${ }^{57}$ Nesse sentido: "Também não se exige tradução de citação de obra jurídica estrangeira, feita em arrazoado. A respeito disso, aliás, o anteprojeto do CPC de 1973 acrescentava um parágrafo único a esse artigo, exigindo versão em português para a citação de autores ou de direito estrangeiro. Esse parágrafo foi suprimido pela Comissão Revisora, evidenciando, com isso, o propósito do legislador de não dar tal alcance à norma" (MARCATO, Antonio Carlos. Op. cit. p.413).

58 “Ao autor cumpre precisar os fatos que autorizam a concessão da providência jurídica reclamada, incumbindo ao juiz conferir-lhes o adequado enquadramento legal" (RSTJ 48/136).
} 
nítida, em todos os países do mundo, mesmo os do sistema anglosaxônico. Desse modo, é não apenas válido como incensurável o recurso às expressões latinas nos atos processuais, inexistindo incompatibilidade aos termos desse princípio.

\section{Z4 DA TAXINOMIA DOS ATOS PROCESSUAIS}

\subsection{Das generalidades}

O Código de Processo Civil oferece uma classificação dos ato processuais, aqui adotada sem maiores críticas, ante a natureza dogmática desse estudo. Esses podem ser divididos nas seguintes espécies: $a$ ) atos da parte; $b$ ) atos do juiz; $c$ ) atos do escrivão ou do chefe de secretaria.

\subsection{Dos atos Da Parte}

\subsubsection{Do conceito}

Os atos da parte abrangem as declarações dos sujeitos processuais primários e secundários - autor, réu, terceiros intervenientes. Sob o aspecto funcional, destinam-se a criar, modificar ou extinguir relações jurídicas no processo. Podem ser unilaterais ou bilaterais, conforme se dê a distribuição de ônus, deveres ou obrigações entre as partes.

Esses atos podem ser associados aos ônus (como os atos postulatórios) ou às faculdades (como os atos de produção de prova). ${ }^{59}$

\subsubsection{Dos atos da parte e plano da eficácia}

Em geral, os atos processuais possuem em si todos os fatores de eficácia, para se usar a terminologia de ANTONIO JunQueIRA DE AZEVEDo quanto aos planos do negócio jurídico e seus elementos (existência), requisitos (validade) e fatores (eficácia) ${ }^{60}$ Dessa mercê, sua simples prática implicará a criação, modificação ou extinção das relações a que visavam interferir.

Os atos de recorrer ou contestar alteram a relação processual, impedindo que preclua a faculdade respectiva (art.183, CPC). Se apresentados no tempo e forma legalmente exigidos, o recurso e a resposta mostram-se plenamente eficazes, não dependendo da intervenção de outros fatores. Há, porém, atos que exigem a integração por outros atos, como autênticos

${ }^{59}$ RODRIGUES, Marcelo Abelha. Elementos de direito processual civil. 2 ed. São Paulo: RT, 2000.p.261.

${ }^{60}$ Negócio jurídico: existência, validade, eficácia. 5 ed. São Paulo: Saraiva, 2002. passim. 
fatores exógenos de eficácia. O caso mais típico é o da desistência da ação, negócio jurídico-processual que depende de homologação por sentença ou acórdão (art.158, CPC). ${ }^{61}$ Sem esse ato do juiz, a conduta da parte, posto existente e válida, reputar-se-á ineficaz relativamente ao processo, mesmo tenha o agente exercido sua faculdade. ${ }^{62}$

Ressalte-se, ainda, que a desistência não obedece ao paralelismo estrito de formas, podendo operar-se de modo oral, consignada no termo próprio, em audiência. ${ }^{63}$ Interessante observar que, nesse tema, a desistência da ação, antes de efetivado o ato citatório, carece apenas da declaração unilateral da parte somado ao fator de eficácia inerente à homologação por sentença.

Se, porém, houve citação válida, só poderá ocorrer a desistência com uma declaração de cunho bilateral, pois dependente da anuência do adversário (art.267, parágrafo quarto, CPC). Também são dependentes do ato homologatório a conciliação (art. 449) e a transação (art.584, III), com algumas particularidades. ${ }^{64}$

Quanto aos recursos, a eficácia de sua desistência é cenáculo de respeitáveis controvérsias. Uma antiga decisão do Supremo Tribunal Federal afirma que, tanto na desistência da ação quanto na desistência do recurso, a eficácia desses atos estará dependente da intervenção

61 "Enquanto não for homologada, por sentença, a desistência da ação, nenhum efeito produz, devendo continuar os atos processuais em todas as suas fases" (Tribunal Federal de Recursos, $5^{\mathrm{a}}$ Turma, Ag n $\mathrm{n}^{\circ}$ 59.927-RS, Rel. o Sr. Min. José Delgado, j. 13.3.1989, v.u., DJU 26.6.1989, p. 11.159).

62 "A raciocinar diferentemente, chegar-se-á ao extremo de supor que, manifestada a renúncia ou a desistência, caberá ao escrivão certificá-las nos autos e dar impulso ao processo independentemente da intervenção homologadora do magistrado" (MONIZ DE ARAGÃO, E.D. Op. cit. p.24). "A necessidade de homologação no caso de desistência, qualquer que seja o momento em que se desiste, atende à relação jurídica processual que se criou" (PONTES DE MIRANDA, Francisco Cavalcanti. Op. cit. p.62).

${ }_{63}$ "Em geral, a desistência do recurso manifesta-se por petição escrita, conforme o caso, ao órgão perante o qual se o interpôs ou ao relator do Tribunal, mas nada impede que tal se faça, oralmente, na própria sessão de julgamento, ainda que iniciada a votação" (Superior Tribunal de Justiça, Terceira Turma, REsp n 21.323-3-GO, Rel. o Sr. Min. Waldemar Zveiter, j. 16.6.1992, v.u., DJU 24.8.1992, p. 12.998).

${ }^{64}$ A conciliação e a transação judicial devem ser tomadas por termo e homologadas por sentença. Há acórdãos entendendo que se exceptuam à regra: a) a transação feita por instrumento público ou particular (RT 541/181, 550/110) ou a transação que não verse sobre direitos contestados em juízo (RT 702/120). 
jurisdicional, ainda que o art.158, CPC, somente aluda à ação, nada cuidando de recurso. ${ }^{65}$

Considera-se, no âmbito desse estudo, de outro modo. Os recursos obedecem a uma lógica diferente. É interesse do Estado abreviar a tramitação dos feitos, especialmente quando o ofício jurisdicional por excelência, que é o vertido em primeiro grado, encerrou-se. Se o direito de ação tem foros constitucionais, o mesmo se não pode dizer do princípio do duplo grau. Assim, aos recursos é dispensável o pronunciamento judicial para tornar eficaz sua desistência. ${ }^{66}$ Ocorrerá preclusão no momento em que manifestada aquela, independentemente de posterior ato extintivo do procedimento recursal. ${ }^{67}$

\subsubsection{Dos atos da parte e capacidade postulatória: fator de eficácia}

Outro fator de eficácia aos atos da parte consiste na capacidade postulatória.

As declarações processuais da parte, à exceção das notoriamente personalíssimas (depoimento, v.g.) e dos vários casos previstos em leis especiais, servem-se do advogado para sua eficaz cognoscência pelo órgão competente. $\mathrm{O}$ advogado, exercente de ministério privado e essencial à administração da justiça (art.133, CF/1988), atua como vetor do acesso à função jurisdicional do Estado, permitindo a plena efetividade ao direito de ação. ${ }^{68}$ Esse conduto exige-se até mesmo para a desistência da ação ou do recurso. ${ }^{69}$

O Estatuto da Ordem dos Advogados do Brasil (Lei no 8.906, de 4-71994) atribui a conseqüência da nulidade aos atos de quem procura em juízo sem ostentar a condição de patrono regularmente inscrito $\left(\operatorname{art} .4^{\circ}\right)$. Em decisão plenária, o Supremo Tribunal Federal considerou inexistentes os atos praticados por mandatário judicial sem comprovada inscrição nos quadros da OAB (MS n ${ }^{\circ}$ 21.730-1-DF-EDcl-AgRg, rel. o Sr. Min. Celso de Mello, j. 2.3.1994, v.u., DJU 22.4.1994, p. 8.942)..$^{70}$

${ }^{65}$ Supremo Tribunal Federal, Primeira Turma, RE n ${ }^{0}$ 65.538-RJ, Rel. o Sr. Min. ANTONIO NEDER, j. 11.3.1975 v.u., DJU 18-4-1975, p.2.524.

${ }^{66}$ NERY JUNIOR, Nelson; NERY, Regina Andrade de Macedo. Código de processo civil comentado e legislação extravagante. 7 ed. São Paulo: RT, 2003. p.560.

${ }^{67}$ DALL'AGNOL, Antônio. Op. cit. p. 239-40.

${ }^{68}$ RTJ $153 / 497$.

${ }^{69}$ RT 643/63; Lex-JTA 139/66.

${ }^{70}$ No mesmo sentido: "Recurso assinado por advogado eliminado dos quadros da Ordem dos Advogados do Brasil. Ato inexistente. Inaplicabilidade do art. 13, CPC, na instância especial" (Superior Tribunal de Justiça. 4 Turma, Ag no 41.748-4-DF-AgRg, rel. o Sr. Min. SÁlvio de Figueiredo, j. 6.12.1993, v.u., DJU 28.2.1994, p. 2.897). 
A esse respeito, pondera-se, no entanto, que melhor seria referir ao fenômeno da ineficácia dos atos processuais, não à sua invalidade. Isso se afirma pelas seguintes razões: a ausência de capacidade postulatória não se insere nas hipóteses de incapacidade civil ou mesmo de invalidez formal. À semelhança dos atos carecedores de legitimação, as declarações jurídico-processuais poderiam ser tidas como válidas em quaisquer circunstâncias, dês que louvadas em agentes capazes, forma lícita ou não prescrita em lei, objeto jurídica e materialmente possível e determinável. Apenas perante o Poder Judiciário, e em termos, pois há várias dispensas legais, as aludidas declarações carecem de um fator de eficácia: o conduto de um profissional inscrito em órgão de classe dotada de assento constitucional. Tanto é assim que se tem mostrado pródiga a jurisprudência em casos de ratificação dos atos realizados em afronta à exigência de capacidade postulatória, como essa recente decisão do Superior Tribunal de Justiça: "Não se decreta a nulidade do processo sem que haja demonstração de prejuízo. Estando o advogado impedido de advogar contra a parte adversa, ficam sanados os atos por ele praticados, desde que ratificados atempadamente, a teor do disposto no art. 13, I, do CPC, sobretudo quando o patrocinado não sabia do impedimento - até porque sem registro na carteira profissional de seu patrono - e o defeito não foi alegado desde quando deveria" (RT 725/172).

Note-se, ainda, que o novo Código Civil, superando antiga polêmica, definiu a invalidade máxima por nulidade como imprescritível e insusceptível de ratificação ou convalidação (art.169). ${ }^{71}$ Por esse motivo, mais ainda sustentável a inserção desse fenômeno no plano da efícácia, propiciando uma justificativa lógico-técnica mais plausível.

É de ser registrado, ainda, quanto à capacidade postulatória, que diversas leis hão cada vez mais segregado sua exigência nos atos em juízo. O que antes era um primado inexpugnável, especialmente com o art.133 da Constituição Federal de 1988, vem-se tornando uma verdadeira exceção. Assim, dispensa-se o advogado, com ressalvas no tocante ao valor da causa e à manifestação recursal, nas ações de alimentos (Lei n ${ }^{0} 5.478$,

\footnotetext{
${ }^{71}$ Art. 169. O negócio jurídico nulo não é suscetível de confirmação, nem convalesce pelo decurso do tempo.
} 
de 25-7-1968, art.2 ${ }^{\circ}$, caput) ${ }^{72}$; ações no âmbito dos Juizados Especiais Cíveis (Lei no 9.099, de 26-9-1995, art.9º 73 $^{73}$, na Justiça do Trabalho (Consolidação das Leis do Trabalho, art.791) ${ }^{74}$ e no procedimento arbitral (Lei no 9.307, de 23-9-1996, art.21, parágrafo terceiro) $)^{75}$.

A recente Lei n ${ }^{\circ} 10.259$, de 12-7-2001, que instituiu os juizados especiais na Justiça Federal ${ }^{76}$, chegou ao clímax desse processo de desvalorização profissional ao prescrever em seu art.10 que "as partes poderão designar, por escrito, representantes para a causa, advogados ou não". Essa norma praticamente restaurou o sistema romano arcaico de representação em juízo, de onde surgiu a expressão patrono (patronus): o plebeu comparecia ao pretor acompanhando de um patrício, seu paráclito, como forma de ser protegido na demanda a que era chamado (litiscontestatio). Não importava o conhecimento jurídico, bastava fosse um patrício.

Ironicamente, o Estatuto da Advocacia, em seu art. $1^{\circ}$, inciso I, haveria de superar todos esses problemas ao dispor que "são atividades privativas de advocacia: I - a postulação a qualquer órgão do Poder Judiciário e aos juizados especiais". Porém, o Supremo Tribunal Federal suspendeu a eficácia dessa indicção, no que se refere a "Juizados Especiais", compreensivo também de Justiça do Trabalho e Justiça de

${ }^{72}$ Art. $2^{\circ}$. O credor, pessoalmente ou por intermédio de advogado, dirigir-se-á ao juiz competente, qualificando-se, e exporá suas necessidades, provando, apenas, o parentesco ou a obrigação de alimentar do devedor, indicando seu nome e sobrenome, residência ou local de trabalho, profissão e naturalidade, quanto ganha aproximadamente ou os recursos de que dispõe.

${ }^{73}$ Art. $9^{\circ}$ Nas causas de valor até vinte salários mínimos, as partes comparecerão pessoalmente, podendo ser assistidas por advogado; nas de valor superior, a assistência é obrigatória. $\S 1^{\circ}$ Sendo facultativa a assistência, se uma das partes comparecer assistida por advogado, ou se o réu for pessoa jurídica ou firma individual, terá a outra parte, se quiser, assistência judiciária prestada por órgão instituído junto ao Juizado Especial, na forma da lei local. $\S 2^{\circ} \mathrm{O}$ Juiz alertará as partes da conveniência do patrocínio por advogado, quando a causa o recomendar. $\S 3^{\circ} \mathrm{O}$ mandato ao advogado poderá ser verbal, salvo quanto aos poderes especiais.

${ }^{74}$ Art. 791. Os empregados e os empregadores poderão reclamar pessoalmente perante a Justiça do Trabalho e acompanhar as suas reclamações até o final.

${ }^{75}$ Art. 21. A arbitragem obedecerá ao procedimento estabelecido pelas partes na convenção de arbitragem, que poderá reportar-se às regras de um órgão arbitral institucional ou entidade especializada, facultando-se, ainda, às partes delegar ao próprio árbitro, ou ao tribunal arbitral, regular o procedimento. (...) $\S 3^{\circ}$ As partes poderão postular por intermédio de advogado, respeitada, sempre, a faculdade de designar quem as represente ou assista no procedimento arbitral.

${ }^{76}$ Sobre a nova lei, consulte-se: SILVA, Luís Praxedes Vieira da. Juizados especiais federais cíveis. Campinas: Millenium, 2003. passim. 
Paz. Esse decisório, de caráter liminar, que serve até hoje de estímulo às deletérias iniciativas legisferantes de supressão das prerrogativas da advocacia, deu-se na ADIn n ${ }^{\circ}$ 1.127-8-DF-Medida Liminar, conforme DJU 14-10-1994, p.27.596.

\subsubsection{Das cotas marginais ou interlineares}

O Código de Processo Civil (art.161) ${ }^{77}$ comina a pena de multa às partes que, em seus atos, lancem cotas interlineares ou marginais no fascículo. É histórica essa proibição, encontradiça nas Ordenações Manuelinas (Livro I, Título 38, parágrafo quarto) e Filipinas (Livro I, Título 48, parágrafo quatorze), bem ainda no Código de Processo Civil de 1939, em seu art.17.

Sua abrangência inclui quaisquer textos, independentemente de seu caráter ofensivo ou não ("as marginais, quaisquer, ou pilheriem, ou revidem, ou respondam, ou perguntem, ou resumam, ou ementem; as interlineares, quaisquer, ou acrescentem ao sentido, ou comentem, ou insinuem"). ${ }^{78} \mathrm{O}$ que importa é coibir inovações na expressão dos atos e termos, propiciando sejam lançadas dúvidas sobre sua autenticidade ou idoneidade. A casuística pretoriana tem relativizado a regra, excluindo de seu alcance o mero sublinhar de passagens dos depoimentos de testemunhas. ${ }^{79}$ Obviamente, não se entende por cotas marginais as expressões, os dísticos ou os símbolos impressos em papel timbrado do escritório dos patronos das partes, mesmo que de gosto duvidoso ou de apelo sentimental, religioso ou político. ${ }^{80}$ Os meros traços a lápis também podem ser tolerados, como anotou Pedro Batista Martins. ${ }^{81}$

A responsabilidade pelas cotas é imputada, por lei, às partes. A multa, que deve ser prestada ao Estado, será inscrita na dívida ativa e cobrada dos litigantes que deram causa à infração. ${ }^{82}$

${ }^{77}$ Art. 161. É defeso lançar, nos autos, cotas marginais ou interlineares; o juiz mandará riscá-las, impondo a quem as escrever multa correspondente à metade do salário mínimo vigente na sede do juízo.

${ }^{78}$ PONTES DE MIRANDA, Francisco Cavalcanti. Op. cit. p.75.

${ }^{79}$ RT 546/88.

${ }^{80}$ RT 631/128.

${ }^{81}$ Comentários ao código de processo civil. 2 ed. Rio de Janeiro: Forense, 1960. v.1. p.84.

82 JTJ 182/158. 
O sistema de responsabilidade por danos processuais é todo sustentado na idéia de que as partes assumem o ônus pela conduta de seus advogados, ficando estes adstritos aos controles disciplinares da Ordem dos Advogados. O grande problema, contudo, é que várias decisões estabelecem uma presunção de que as cotas foram (ou deveriam ter sido) lançadas pelos advogados ${ }^{83}$, o que, em última análise, penaliza a parte. O mais correto seria apurar esse ato, mediante o direito ao contraditório, com o provimento que resolva esse ponto submetido a recurso.

\subsection{Dos ATos do JUIZ}

\subsubsection{Da relação de atos do juiz: caráter extensivo. Dos pronunciamentos judiciais.}

Os atos do juiz estão enumerados no art.162 do Código de Processo Civil: sentenças, decisões interlocutórias e despachos. O art.163 acresce a lista mencionando os acórdãos.

Para fins desse estudo, não se procederá a um inventário mais profundo sobre a natureza e a distinção desses atos judiciais. Não é esse o objetivo do autor, nem a isso se propõe um trabalho eminentemente dogmático. A tanto, recomenda-se, para uma visão menos perfunctória, a leitura de CÂndido Rangel Dinamarco ${ }^{84}$ e José Carlos Barbosa Moreira ${ }^{85}$, cujas obras são fundamentais sobre a matéria, tanto pela elegância de seu conteúdo, quanto pelo rigor científico emprestado ao tema.

Um primeiro óbice a ser resolvido diz com o caráter extensivo ou exaustivo do art.162, CPC. Nelson Nery Junior e Rosa Maria de Andrade Nery $^{86}$, José Carlos Barbosa Moreira ${ }^{87}$, E. D. Moniz de Aragão ${ }^{88}$ e MARCEloAbelHa Rodrigues ${ }^{89}$ entendem que apenas pronunciamentos judiciais estariam ali mencionados, deixando-se a margem diversos outros atos materiais (tomar o depoimento das testemunhas; interrogar as

${ }^{83}$ RT 578/158; RF 291/238.

${ }^{84}$ Fundamentos do processo civil moderno. 4 ed. Revista e atualizada por Antônio Rulli Neto. São Paulo: Malheiros, 2001. v.1. p.219-227.

${ }^{85}$ Comentários ao código de processo civil. 8 ed. revis. e atual. Rio de Janeiro: Forense, 1999. v.5. p.238-244; O novo processo civil brasileiro. 20 ed. revis. e atual. Rio de Janeiro: Forense, 2000. p.114.

${ }^{86}$ Op. cit. p.562.

${ }^{87}$ Comentários ao código... p. 238.

${ }^{88}$ Op. cit. p.32.

${ }^{89}$ Op. cit. p.261. 
partes; fazer inspeção judicial). E é absolutamente correto esse parecer, tanto pela simples observância da topografia legislativa (arts.316, 416, $440,1.122$, CPC), como pelo fato de se não manifestar o juiz através de pronunciamentos nesses casos. Repete-se com CÂNDIDO RANGEL DinAMARCO ${ }^{90}$ : "Melhor seria se se dissesse que os atos do juiz se classificam em atos materiais e provimentos, subdividindo-se estes naquela forma que o art.162 indica".

Por conseguinte, os chamados atos do juiz são compreensivos dos pronunciamentos judiciais e dos atos materiais. ${ }^{91}$ No direito italiano, prefere-se a expressão atti processuali degli organi giurisdizionali (atos processuais dos órgãos jurisdicionais), conforme UGO Rocco. ${ }^{92}$

\subsubsection{Das espécies de pronunciamentos judiciais: visão positiva}

Superada essa questão, vê-se que a lei cuidou de conceituar os atos do juiz (rectius, pronunciamentos) num raro exercício de coadjuvação ao ofício doutrinário, talvez como forma de dissipar polêmicas inúteis quanto à natureza de tão importantes atos.

Tem-se, a semelhante respeito, que, em sede positiva, a sentença é o ato pelo qual o juiz põe termo ao processo, decidindo ou não o mérito da causa. A decisão interlocutória é o ato pelo qual o juiz, no curso do processo, resolve questão incidente. O despacho corresponde aos demais atos do juiz praticados no processo, de ofício ou a requerimento da parte, a cujo respeito a lei não estabelece outra forma. O acórdão é o julgamento proferido pelo tribunal.

Como resultante, torna-se possível fazer outras distinções entre aqueles atos no plano dos recursos: $a$ ) as sentenças são impugnáveis mediante o recurso de apelação ou embargos declaratórios (art.513, CPC); b) as decisões interlocutórias agraváveis ou sujeitas a embargos declaratórios (art.522, CPC) ${ }^{93}$ c) os despachos são irrecorríveis (art.504, CPC), salvo quando causarem gravame às partes, hipótese em que perdem essa natureza e passam a suportar o recurso de agravo; d) os acórdãos, além dos recursos no âmbito do próprio grau de jurisdição, podem ser confrontados com as irresignações constitucionais.

\footnotetext{
${ }^{90}$ Op. cit. p. 220.

${ }^{91}$ Humberto Theodoro Júnior (op. cit. p.19) denomina-os, respectivamente, atos decisórios propriamente ditos e atos executivos.

${ }^{92}$ Op. cit. p.222.

${ }^{93}$ Sobre a recorribilidade das decisões, confira-se: CAVALCANTE, Mantovanni Colares. Regime jurídico dos agravos. São Paulo: Dialética, 1998. passim.
} 
Remonta ao Direito Romano a origem das expressões sentença e (decisão) interlocutória, extraídas de um fragmento atribuído a Modestino: "Res iudicata dicitur, quae finem controversiarum pronuntiatione accipit: quod vel condemnatione vel absolutione contingit", constante do L.1, D, de re iudicata et de effectum sententiarum et de interlocutionibus, 42, $1 .{ }^{94}$ A doutrina tradicionalmente aduz que essa passagem permite inferir a distinção entre os pronunciamentos. ${ }^{95}$ A sentença corresponderia ao atual juízo de mérito, enquanto a interlocutória referir-se-ia aos demais juízos no curso do processo, que não solucionariam o litígio. ${ }^{96}$

A palavra despacho evoca desimpedimento, fazer ir adiante, algo que é expedito. São ordens judiciais que se vinculam ao andamento do processo (rectius, que permitem seu andamento), quando se faz necessário por determinação legal, seja ex officio, seja mediante provocação das partes. ${ }^{97}$ Sua nota característica está em ser destituído de conteúdo decisório. ${ }^{98}$

\subsubsection{Das espécies de pronunciamentos judiciais: visão doutrinária}

\subsubsection{Das generalidades}

A classificação acima exposta louva-se exclusivamente na interpretação literal do Código de Processo Civil. Esses conceitos, entretanto, merecem alguns reparos, o que se faz em respeito a certos parâmetros doutrinários bem sedimentados, capazes de informar o estado-da-arte da Ciência Processual nesse tema.

\subsubsection{Das decisões impropriamente denominadas de despachos} e dos despachos que verdadeiramente são decisões

Indispensável advertir que, parafraseando SHAKESPEARE, uma decisão interlocutória não deixará de sê-la, acaso venha a ser chamada de despacho. ${ }^{99}$ Com efeito. É lastimavelmente comum encontrar na praxe

${ }^{94}$ CORPUS IURIS CIVILIS Academicum Parisiense. Opera et cura C. M. Galisset, Duodecima editio, Lutetiae Parisiorum: Rectores V. Renault et Consociati, MDCCCLXXXVIII.

${ }^{95}$ Por todos: THEODORO JÚNIOR, Humberto. Op. cit. p.207.

${ }^{96}$ Em sentido contrário: PONTES DE MIRANDA, Francisco Cavalcanti. Op. cit. p.78.

${ }^{97}$ REZENDE FILHO, Gabriel José Rodrigues de. Curso de direito processual civil. 5 ed. São Paulo: Saraiva, 1957. v.3. p.15.

${ }^{98}$ RODRIGUES, Marcelo Abelha. Op. cit. p.263.

99 "O ato pode ter externa e formalmente característica de despacho, mas, porque causou gravame, decidiu questão incidente, transmudando-se em decisão interlocutória, pois somente estas podem causar prejuízos a parte ou interessado" (NERY JUNIOR, Nelson; NERY, Rosa Maria de Andrade. Op. cit. p.563). 
forense a denominação de despacho ou despacho interlocutório para referir autênticas decisões (concessivas de liminar, denegatórias de recursos, indeferindo produção de provas). Nesses casos, como de resto em vários outros, deve-se levar menos em conta a nomenclatura erroneamente atribuída (até mesmo em lei) e mais a eficácia do ato judicial $^{100}$, em especial, sua potencialidade ofensiva ao direito da parte. ${ }^{101}$ Isso no que concerne apenas ao uso equívoco dos termos pelos operadores jurídicos em seus ofícios forenses. O Código de Processo Civil também é merecedor de críticas, pois, em vários artigos, alude a despachos, que, em verdade, são decisões. No art.126, está afirmado que o "juiz não se exime de sentenciar ou despachar alegando lacuna ou obscuridade da lei”. Aqui, o Código incluiu a espécie decisão na categoria dos despachos, devendo, se não pretendia omitir estes últimos, incluir aquela, para dar a necessária abrangência à norma. $\mathrm{O}$ art.331 cuida do saneamento do processo. Essa realidade é tida por alguns como uma atividade do juiz, complexa, portanto, incompatível com um ato único, geralmente chamado de despacho saneador. Entrementes, o art. 338 mantém esse instituto na lei processual, ao predicar que "a carta precatória e a carta rogatória não suspendem o processo, no caso de que trata o art. 265, IV, $b$, senão quando requeridas antes do despacho saneador". Ora, havendo um ato sanatório da relação processual, sua natureza é precipuamente decisória, jamais a de um despacho. ${ }^{102}$ Figurese, ainda, o despacho liminar da inicial, conforme o art.285, que, na espécie negativa possui notório caráter decisivo, sem falar nas situações em que, ao ser meramente positivo, também exibe essa natureza. ${ }^{103}$ Mais grave ainda é o exemplo do art.930, que se vale da palavra despacho para qualificar o ato que "deferir ou não a medida liminar". Seria, por

\footnotetext{
${ }^{100}$ Assim é que o Superior Tribunal de Justiça, na Súmula n ${ }^{\circ} 118$, pronunciou que "o agravo de instrumento é o recurso cabível da decisão que homologa a atualização do cálculo do contador".

101 "A distinção entre o despacho simplesmente ordinatório e o de conteúdo decisório deve ser buscado no gravame que o provimento judicial impõe à parte interessada" (RT 508/199).

${ }^{102}$ Nesse sentido: BARBOSA MOREIRA, José Carlos. Comentários ao código...p.243: “O exemplo mais frisante é o 'despacho saneador' (art.338), que em todo caso tem por si a tradição...".

${ }^{103}$ No procedimento monitório (art.1.102b, CPC), o juiz, estando a petição inicial devidamente instruída, "deferirá de plano a expedição do mandado de pagamento ou de entrega da coisa no prazo de quinze dias".
} 
assim, irrecorrível o pronunciamento judicial acerca da liminar possessória, por a lei denominá-lo despacho? Obviamente que não. Prevalece o dito acima: o que importa é a finalidade-eficácia do ato judicial. ${ }^{104}$

Merece transcrição a adequada síntese de José CARLos BARBosa MoreIrA: “...todo e qualquer 'despacho' em que o órgão judicial decida questão, no curso do processo, pura e simplesmente não é despacho, ainda que assim the chame o texto: encaixando-se no conceito de decisão interlocutória (art.162, parágrafo segundo), ipso facto deixa de pertencer à outra classe". ${ }^{105}$

\subsubsection{Das decisões e das sentenças: uma relação espécie-espécie que se pode tornar gênero-espécie}

Outro problema que a doutrina identificou no texto do Código de Processo Civil foi a insuficiência da relação espécie-espécie que o art.162 imputou às decisões e às sentenças, qualificadas como dois entes do gênero atos do juiz. José Carlos Barbosa Moreira propõe que se conceba uma relação gênero-espécie entre aqueles pronunciamentos. ${ }^{106}$ A categoria decisão seria gênero, com as espécies decisão final (sentença) e decisão interlocutória. ${ }^{107}$

De fato, se examinado o Código de Processo Civil, fica mui evidente a propriedade da organização daqueles pronunciamentos num sentido gênero-espécie. $\mathrm{O}$ art. 55, inciso I, define que "transitada em julgado a sentença, na causa em que interveio o assistente, este não poderá, em processo posterior, discutir a justiça da decisão, salvo se alegar e provar que: I - pelo estado em que recebera o processo, ou pelas declarações e atos do assistido, fora impedido de produzir provas suscetíveis de influir na sentença". Não se pode discutir a justiça da decisão, a qual, é uma

${ }^{104}$ A jurisprudência tem sido pacífica em reconhecer como agravável o ato judicial definido no art.930 como despacho, subtraindo-o, portanto, a essa qualificação errônea (RT 482/109, RT 490/99, RT 495/195, RF 322/218, RT 480/174).

${ }^{105}$ In. Comentários ao código...p. 243.

${ }^{106}$ E. D. Moniz de Aragão (op. cit.p.37) apresenta opinião minoritária e divergente, compreendendo as decisões como espécies de despachos: "De fato, a fazer uma distinção conceitual, há dois tipos de pronunciamentos do juiz: despachos, através dos quais o processo caminha para a sentença, e esta, que lhe põe fim. As chamadas decisões interlocutórias nada mais são do que despachos, fadadas a solucionar incidentes que poderiam ou não impedir a marcha do processo para a sentença, não obstante as opiniões doutrinárias que procuram demonstrar-lhes a existência e a utilidade". 
sentença. O art.495 fala por si mesmo: "O direito de propor ação rescisória se extingue em dois (2) anos, contados do trânsito em julgado da decisão". ${ }^{108}$

\subsubsection{Da peculiaridade dos acórdãos}

Os membros dos tribunais podem praticar todos os atos assinalados nos arts.162 e 163, CPC, à exceção das sentenças. ${ }^{109}$ Assim, seus pronunciamentos, ainda que em ações originárias, serão: $a$ ) acórdãos, se colegiados; $b$ ) decisões, se singulares. ${ }^{110}$ Cabe-lhes, evidentemente, exarar despachos.

As decisões monocráticas dos relatores, em especial quando observadas a lume das recentes reformas do Código de Processo Civil, podem assumir uma ambígua posição, ao estilo das que denegam o seguimento a recurso manifestamente inadmissível, improcedente, prejudicado ou em confronto com súmula ou com jurisprudência dominante de tribunal superior (art.557, CPC). Nesse caso, não ensejam a lavratura de acórdão ${ }^{111}$, mas, qualificam-se como decisões.

É de ser realçado que, muita vez, o Código de Processo Civil usa da palavra sentença com espectro abrangente dos acórdãos. Onde se lê sentença, nesses casos, está-se deparando com um qualificativo de decisão, portanto, abrangente também de acórdão (arts. 485, caput, incisos VII, VIII e $\S 1^{\mathrm{o}}$; 487, inciso III, $b$; 489; 494; 497; 503; 505; 572; 574; 575, inciso IV; 580, parágrafo único; 584, inciso I, II e IV; $586 \S \S 1^{\circ}$ e $2^{\circ}, 587,588$ e $\S$ ún., 589, 590, 603-"caput”, $605 \S$ ún., 606-I, 614-I, 624, $627 \S 2^{\circ}, 641,732,733,735,741-V I, 744,811-I$, $817,918,945,958,1.030,1.060-\mathrm{II})$.

${ }^{108}$ CÂndido Rangel Dinamarco (Op. cit. p.223), até por essa confusão onomástica, entende inaplicável esse constructo teórico, propondo o uso da palavra provimento para qualificar sentenças e decisões: "Diante disso, fica difícil o entendimento da palavra, que é tão equívoca e, em alguns casos, causadora de dúvidas interpretativas. A tendência, no linguajar forense cotidiano, é dar-lhe o sentido mais amplo, que ela tem no art.522, onde vale por provimento".

${ }^{109}$ Em sentido contrário, entendendo que o membro singular de tribunal pode proferir sentença: NERY JUNIOR, Nelson; NERY, Rosa Maria de Andrade. Op. cit. p.565.

${ }^{110}$ Contrariamente, E. D. Moniz de Aragão (op. cit. p.45) afirma: "qualquer pronunciamento de tribunal - em processo regulado pelo Código - terá essa denominação; não importa que seja despacho, decisão interlocutória ou sentença, que haja ou não solucionado o mérito da causa".

${ }^{111}$ Superior Tribunal de Justiça. $4^{\mathrm{a}}$ Turma, Ag n ${ }^{\circ}$ 19.156-0-SP-AgRg, Rel. o Sr. Min. SÁlVIo de FigueIREDO, j. 4.8.1992, negaram provimento, v.u., DJU 14.9.1992, p. 14.977. 


\subsubsection{Da assinatura do juiz como elemento de existência dos pronunciamentos}

A assinatura do juiz é indispensável para que existam os despachos, as decisões, as sentenças e os acórdãos (art.164, CPC). Trata-se de elemento de existência, não de requisito formal de validade ou fator de eficácia. Sem a firma do magistrado, simplesmente haverá uma minuta de ato, não um ato perfeitamente composto e capaz de ser confrontando no plano da validade ou, ainda, hábil a produzir efeitos. Com absoluta razão este acórdão: "sentença sem assinatura, mais do que nula, é inexistente" (Tribunal Federal de Recursos. 4 Turma. AC no 46.417-SP, Rel. o Sr. Min. Bueno de Souza, j. 12.11.1980, v.u., DJU 18.12.1980, p. 10.858). ${ }^{112}$

É de ser ponderada, no entanto, a aplicação rigorosa dessa regra. José Joaquim Calmon de Passos ${ }^{113}$, CÂndido Rangel Dinamarco ${ }^{114}$ e Ovídio AraúJo BAPTISTA DA SiLva ${ }^{115}$ têm desenvolvido teses quanto ao caráter específico das nulidades no âmbito da processualística, marcadamente no sentido de saneamento e conversão dos atos. A importância desse novo enfoque dá-se na medida em que permite seja revisto o posicionamento dogmático atual a respeito. Bem a propósito, num acórdão reproduzido em RT 784/362, o Tribunal de Justiça de Minas Gerais conheceu do seguinte caso: uma pessoa moveu ação contra o Instituto de Previdência dos Servidores do Estado, a qual teve seus pedidos julgados procedentes em primeiro grado jurisdicional. A autarquia recorreu e houve remessa obrigatória. Admitido o apelo, o relator percebeu, tempos depois, que o juiz não assinara a sentença. Por conseqüência, o Tribunal acordou que nem a publicação regular da sentença, nem o silêncio das partes, que arrazoaram e contra-arrazoram o recurso, convalidara o ato. Mais ainda: não seria possível ratificação com posterior assinatura: o que não existe é impassível de ratificação. A

112 No mesmo sentido: RT 508/64; RT 750/280. Ainda: "Nem mesmo a publicação regular da sentença não assinada lhe imprime força de ato processual" (JTACivSP 73/355).

${ }^{113} \mathrm{In}$. Esboço de uma teoria das nulidades aplicada às nulidades processuais. Rio de Janeiro: Forense, 2002. passim.

${ }^{114}$ In. Instituições de direito processual civil. 4 ed. São Paulo: Malheiros, 2002. v.2. p. 600-601.

${ }^{115}$ In. Curso de processo civil. 3 ed. Porto Alegre: Sérgio Antônio Fabris Editor, 1996. v.1. passim. 
Corte declarou, de ofício, a inexistência do decisum primitivo. ${ }^{116}$ Todos os atos subseqüentes foram contaminados e tidos por imprestáveis. A incidência dessa premissa, nesses termos, foi, como diriam os antigos romanos, um típico exemplo de summum ius, summa injuria.

Para E. D. Moniz de Aragão, no respeitante aos acórdãos, é possível que a assinatura seja lançada posteriormente: "Como o vocábulo acórdão designa precipuamente a representação escrita de um julgamento, cuja existência é anterior à sua documentação, esta lhe dá apenas a forma, não o ser. Em alguns casos, tão logo proferido o julgamento, põem-se em prática atos necessários à sua imediata execução, conquanto o acórdão ainda não esteja redigido nem subscrito. É o que sucede, por exemplo, com a comunicação, incontinenti, da concessão ou denegação do mandado de segurança à autoridade, conforme dispõe o art.206 do Regimento do Supremo Tribunal, e se pratica nos demais. Ocorre, ainda, com a notificação, ato contínuo, de haver sido deferido habeas corpus (Código de Processo Penal, art.665) ou, no julgamento de qualquer recurso, bem como da revisão criminal, a expedição imediata de alvará de soltura em favor do preso, mesmo que apenas mais tarde seja redigido o acórdão respectivo". ${ }^{117}$

\subsubsection{De outros elementos, requisitos e fatores dos atos judiciais}

Em tese, sentenças e acórdãos devem: $a$ ) indicar corretamente quais são as partes (salvo na hipótese de exceção ao principio da publicidade dos atos processuais, como visto); $b$ ) descrever os fatos por aquelas relatados; $c$ ) enunciar as principais ocorrências no desenvolvimento da relação processual; $d$ ) sumariar o pedido; $f$ ) motivar e fundamentar suas conclusões; $g$ ) dispor sobre as questões de fato e de direito, resolvendoas (art.458 c/c art.165, CPC). Embora o art.458, CPC, use da expressão "requisitos essenciais" para as sentenças, mais técnico é reconhecer naquela indicção a presença de elementos existenciais, requisitos de validade e fatores de eficácia da sentença, graduando-os conforme sua vocação para que se emita um juízo de sentença inexistente, sentença inválida ou sentença ineficaz.

${ }^{116}$ Tribunal de Justiça de Minas Gerais, 4 ${ }^{a}$ Câmara. AC no 172.118-2/00, Rel. o Sr. Des. Célio César PAdUAni, j. 4.5.2000, in RT 784/362.

${ }^{117}$ Op. cit. p.48. 
As decisões interlocutórias exigem fundamentação ${ }^{118}$, a qual pode ser concisa, porém capaz de permitir sejam inferidos os móveis que a determinaram. A inobservância desse requisito conduz a sua nulidade. ${ }^{119}$ Antes de encerrado este parágrafo, necessária uma explicação. Foi dito que em tese as sentenças devem apresentar os elementos, requisitos e fatores do art.458, CPC. Tal encontra justificativa no fato de haver muitas sentenças que os não exigem em sua plena majestade, como, v.g.: a) a sentença que dá pela existência de coisa julgada não precisa ter o formalismo exigido pelo art. 458, desde que esteja suficientemente fundamentada (RTFR 111/89); b) as sentenças meramente homologatórias não precisam de fundamentação extensa (RT 616/57), inclusive as homologatórias de transação (RT 621/182).

Quanto aos acórdãos, é lícito que mencionem o relatório da sentença, acolhendo-o e transmigrando-o para seu próprio conteúdo. ${ }^{120}$

Os despachos, em tese, não necessitam de fundamentação. Há, todavia, casos como o do art.209, CPC, que prescreve a necessidade de "despacho motivado" para a recusa ao cumprimento de carta precatória.

\subsection{Dos ATOS DO ESCRIVÃo OU DO CHEFE DE SECRETARIA}

O PAPA INOCÊNCIO III, que tantas contribuições propiciou ao Direito, sobressaindo-se dentre todas a teoria do corpo místico, primícias das modernas construções sobre a natureza da pessoa jurídica, não se demitiu de sua condição de papa de Bolonha. Por uma decretal de 1216, a fim de conferir maior dignidade aos processos e certeza futura quanto à sua validez, determinou que todos seus atos fossem escritos por uma pessoa pública ou duas pessoas idôneas. O escrivão, de mero fautor de textos, tornava-se um agente da Justiça, conforme os relatos de JoÃo MENDES DE AlMEIDA JúNIOR. ${ }^{121}$

Os atos do escrivão ou do chefe de secretaria ${ }^{122}$ podem ser descritos como atos de fé pública, inerentes à organização formal e à marcha dos processos, bem assim atos de certificação, possibilitando-lhes firmar a

\footnotetext{
${ }^{118}$ RF 306/200.

${ }^{119}$ RJTJSP 130/340; PJ 26/130.

${ }^{120}$ RTJ $103 / 784$.

${ }^{121}$ Direito judiciário brasileiro. 4 ed. Rio de Janeiro: Freitas Bastos, 1954. p. 231.

${ }^{122}$ José Manoel de Arruda Alvim denomina-os atos de auxílio à jurisdição (Manual de direito processual civil. 4 ed. São Paulo: RT, 1996. v.1.p.391).
} 
autenticidade "dos atos que se passaram na sua presença ou figuram nos livros, papéis e autos de seu ofício" "123 Há, ainda, a classificação de seus atos em de documentação ou de comunicação.

Os atos meramente ordinatórios (art.162, parágrafo quarto, CPC), embora submetidos à seção dos atos judiciais, devem ser inseridos no rol dos praticados de ofício pelo servidor, independentemente de despacho e sob a supervisão do juiz. Assim, não se julga correto considerá-los uma espécie de despacho, ao fundamento exclusivamente topográfico de estarem localizados na secção dos atos do juiz. Nesse sentido MarCelo Abelha Rodrigues: "Acreditamos que não foi criada pela Lei n. 8.952/94 uma nova hipótese de despacho, já que a reforma apenas 'legalizou' uma situação legitimada pela prática judiciária e cartorária. (...) O pronunciamento decorrente da revisão é que poderá assumir a natureza de despacho ou de decisão interlocutória, caso em que poderá ser objeto do agravo. Contudo, ratifica-se, o recurso é contra ato do juiz (proferido na sua revisão) e não do cartorário, que é projeção lógica do princípio do impulso oficial". ${ }^{124}$

Podem ser mencionados como atos dos serventuários: $a$ ) autuação; $b$ ) registro; $c$ ) numeração e assinalação (rubrica) das páginas dos autos; $d$ ) juntadas; $e$ ) liberação do fascículo para vistas às partes.

A forma desses atos demanda a inexistência de rasuras, espaços em branco, quotas interlineares ou entrelinhas, salvo as correções expressamente determinadas (art.171, CPC). É mais uma homenagem que se presta à tradição jurídica peninsular, porquanto identificável nas Ordenações Reinóis de Dom Manuel (Livro I, Título LIX, princ.) e de Dom FiLIPE (Livro I, Título LXXVIII, parágrafo quarto).

Francisco Cavalcanti Pontes de Miranda define o que sejam esses vícios: "Rasura é todo ato do que roeu, raspou o papel, ou destruiu a tinta que antes estava. (...) Entrelinhas, conforme o nome diz, são escritos, letras, algarismos ou sinais que não fiquem nas linhas (pautas) e se insiram entre duas ou mais linhas. Ou são corretivas (cancelatórias); ou precalares, ou intercalares, ou poscalares, em relação a alguma palavra ou parte de

\footnotetext{
${ }^{123}$ MONIZ DE ARAGÃO, E. D. Op. cit. p.51.

${ }^{124}$ Op. cit.p.264.
} 
linha; ou são simplesmente interespaciais, quando o escrivão lança entre duas linhas proposição que faça sentido. Essas não se intercalam entre palavras, ou parte da linha, ou entre sílabas, ou letras, nem se põem antes ou depois de palavras: são entrelinhas autônomas. (...) Emendas, na terminologia do Código, é todo ato que, sem entrelinhar, nem rasurar, corrige ou muda o que se escreveu. Em vez de ser puro acréscimo, ou destruição, é acréscimo com mudança de alguma letra, sílaba ou palavra inteira, afeiçoando-lhe os traços a ponto de alterá-las e acomodá-las a outra letra, sílaba ou palavra inteira, ou destruição parcial e substituição parcial (emenda+rasura). (...) Ressalva é comunicação escrita, certificativa de que algo de anormal se passou na elaboração material da peça processual, e explicativa de que traduz o que se pretendia dizer e realmente (1) se passa a dizer, ou (2) foi dito". ${ }^{125}$

Interessante, ainda, que os atos e termos do processo serão redigidos (rectius, escritos, datilografados ou digitados) "com tinta escura e indelével, assinando-os as pessoas que neles intervieram" e sem abreviaturas (art.169, CPC). Um curioso julgado admite compreender no conceito de tinta escura a espécie verde-escura (RT 725/150).

${ }^{125}$ Op. cit.p.95-96. 


\section{Bibliografia}

ALMEIDA JÚNIOR, João Mendes de. Direito judiciário brasileiro. 4 ed. Rio de Janeiro: Freitas Bastos, 1954.

AZEVEDO, Antonio Junqueira de. Negócio jurídico: existência, validade, eficácia. 5 ed. São Paulo: Saraiva, 2002.

.Ciência do direito, negócio jurídico e ideologia. In. DI FRANCESCO, José Roberto Pacheco. Estudos em homenagem ao professor Silvio Rodrigues. São Paulo: Saraiva, 1989.

BAPTISTA DA SILVA, Ovídio Araújo. Curso de Processo Civil. 3 ed. Porto Alegre: Sérgio Antônio Fabris Editor, 1996. v.1.

BARÃO DE RAMALHO. Praxe. Rio de Janeiro: (s.e), 1867.

BARBOSA MOREIRA, José Carlos. Comentários ao Código de Processo Civil. 8 ed. revis. e atual. Rio de Janeiro: Forense, 1999. v.5.

. O novo Processo Civil Brasileiro. 20 ed. revis. e atual.

Rio de Janeiro: Forense, 2000.

.Uma novidade: o Código de Processo Civil inglês. In Revista de Processo, v.25, n.99, p.4-83, jul./set. 2000.

CALMON DE PASSOS, José Joaquim. Esboço de uma teoria das nulidades aplicada às nulidades processuais. Rio de Janeiro: Forense, 2002.

CAVALCANTE, Mantovanni Colares. Regime jurídico dos agravos. São Paulo: Dialética, 1998.

CORPUS IURIS CIVILIS Academicum Parisiense. Opera et cura C. M. Galisset, Duodecima editio, Lutetiae Parisiorum: Rectores V. Renault et Consociati, MDCCCLXXXVIII.

DALL'AGNOL, Antônio. Comentários ao Código de Processo Civil. São Paulo: RT, 2000. v.2.

DINAMARCO, Cândido Rangel. A instrumentalidade do processo. 10 ed. São Paulo: Malheiros, 2002. 
Fundamentos do processo civil moderno. 4 ed.

Revista e atualizada por Antônio Rulli Neto. São Paulo: Malheiros, 2001. v.1.

Instituições de direito processual civil. 4 ed. São

Paulo: Malheiros, 2002. v.2.

LOPES DA COSTA, Alfredo de Araújo. Direito processual civil brasileiro. 2 ed. revista. Rio de Janeiro: Forense, 1959. v.2.

LOTUFO, Renan. Comentários ao Código Civil Brasileiro. São Paulo: Saraiva, 2002. v.1.

MARCATO, Antonio Carlos (Org.) Código de Processo Civil interpretado. São Paulo: Atlas, 2004.

MARTINS, Pedro Batista. Comentários ao Código de Processo Civil. 2 ed. Rio de Janeiro: Forense, 1960. v.1.

MERWE, C. G. van der. A comparative study of the distribution of ownership rights in property in an apartment or condominium scheme in common law, civil law and mixed law systems. In. Georgia Journal of International and Comparative Law, v.31, n.1, p.101-137, fall 2002.

MONIZ DE ARAGÃO, E. D. Comentários ao Código de Processo Civil. 9 ed. rev., atual. Rio de Janeiro: Forense, 1998. v.2.

NERY JUNIOR, Nelson; NERY, Regina Andrade de Macedo. Código de processo civil comentado e legislação extravagante. 7 ed. São Paulo: RT, 2003.

NORONHA, Fernando. Direito das obrigações. São Paulo: Saraiva, 2003.

REZENDE FILHO, Gabriel José Rodrigues de. Curso de Direito Processual Civil. 5 ed. São Paulo: Saraiva, 1957. v.3.

ROCCO, Ugo. Trattato di diritto processuale civile. Torino: UTET, 1957.

RODRIGUES, Marcelo Abelha. Elementos de Direito Processual Civil. 2 ed. São Paulo: RT, 2000.

RODRIGUES JUNIOR, Otavio Luiz. Revisão judicial dos contratos: Teoria da imprevisão e autonomia da vontade. São Paulo : Atlas, 2002.

ROMANO, Salvatore. Autonomia privata. Milano: Giuffrè, 1957. 
SAMPAIO, José Adércio Leite. Direito à intimidade e à vida privada. Belo Horizonte: Del Rey, 1998.

SILVA, Luís Praxedes Vieira da. Juizados especiais federais cíveis. Campinas: Millenium, 2003.

PONTES DE MIRANDA, Francisco Cavalcanti. Comentários ao Código de Processo Civil. Atualizado por Sergio Bermudes. 4 ed. Rio de Janeiro: Forense, 1998. v.3.

THEODORO JÚNIOR, Humberto. Curso de Direito Processual Civil. 39 ed. Rio de Janeiro: Forense, 2003. v.1.

VASCONCELOS, Arnaldo. Teoria da norma jurídica. 2 ed. Rio de Janeiro: Forense, 1986.

VIANA, Juvêncio Vasconcelos. Efetividade do processo em face da fazenda pública. São Paulo: Dialética, 2003.

VILLAÇAAZEVEDO, Álvaro. Código Civil Comentado. São Paulo: Atlas, 2003. v.2. 